\title{
Predicting the economic impact of the 2010 FIFA World Cup on South Africa
}

\author{
Heinrich R. Bohlmann* and Jan H. van Heerden \\ Department of Economics University of Pretoria Pretoria 0002, South Africa \\ E-mail: heinrich.bohImann@up.ac.za \\ E-mail:jan.vanheerden@up.ac.za Corresponding author
}

\begin{abstract}
The impact of the sporting industry on economic decision making has increased dramatically since the global media explosion in the 1980s. Tourism and advertising revenues generated by mega-events such as World Cups or Olympic Games have become a major boost to the economies of hosting nations. In addition, globalisation has placed great emphasis on the importance of Foreign Direct Investment (FDI), especially to developing countries.

This paper seeks to examine the impact of the 2010 FIFA World Cup on the South African economy. Using a 32-sector Computable General Equilibrium (CGE) model, the various shocks on the economy, such as infrastructure developments, increased tourism and financing implications, are modelled. Results are shown and carefully explained within the context of the model. It is found that in the short term, there would only be a favourable outcome in the economy should financing be shared between higher present taxes and revenue generated from future economic growth and private investment.
\end{abstract}

Keywords: Computable General Equilibrium; CGE; mega-events.

Reference to this paper should be made as follows: Bohlmann, H.R. and van Heerden, J.H. (2008) 'Predicting the economic impact of the 2010 FIFA World Cup on South Africa', Int. J. Sport Management and Marketing, Vol. 3, No. 4, pp.383-396.

Biographical notes: Heinrich Bohlmann is a Lecturer in the Department of Economics and member of the African Institute of Economic Modelling at the University of Pretoria. He holds an MCom from the University of Pretoria. In 2006, he wrote an essay on measuring the economic impact of FIFA 2010 using Computable General Equilibrium (CGE) techniques. His other areas of specialisation include macroeconomics and development economics.

Jan van Heerden is the Chair of the School of Economic Sciences and Professor of Economics at the University of Pretoria. He holds a PhD from the Rice University in Houston, Texas, and specialises in Computable General Equilibrium (CGE) Modelling. He has been focusing mostly on the environmental economic applications of the CGE model, such as the effects of energy and water taxes on the South African economy. His most recent paper appeared in The Energy Journal, while other papers have been accepted in Water Resources Research and Ecological Economics.

\section{Introduction}

Sports have always been an integral part of the South African culture. Since the country's return to the international fold in 1991, sports have also become an increasingly important part of the economy. The hosting of mega-events, such as the Olympic Games, is generally reserved for developed countries with an already advanced infrastructure. The FIFA World Cup tournament has, since its inception, been held in countries with a rich football tradition, and consequently, in countries with sufficient football infrastructure. However, motivated by a desire to promote football and capitalise on its growing popularity elsewhere in the world, FIFA has begun designating host countries outside of Europe and Latin America. This strategy by FIFA has led to the first-ever World Cup to be hosted on African soil. South Africa's successful bid to host the 2010 FIFA World Cup poses a unique opportunity to assess the impact of such a large-scale event on a developing economy.

The purpose of this paper is to measure the impact of hosting the 2010 FIFA World Cup on the South African economy, using a 32-sector Computable General Equilibrium (CGE) model. 
The CGE model is solved using the GEMPACK software package. The results aim to give a more accurate and detailed estimate of the economic impact of the 2010 World Cup than is currently available.

\section{Literature in brief}

The first economic impact study of hosting the Olympic Games, conducted for the Los Angeles Games of 1984, was a direct result of the interest generated by reports that Montreal declared a considerable financial deficit from the 1976 Games. Subsequently, many studies have been done on the wide-ranging and diverse impacts of sporting events on economies.

An economic impact study of the Rugby World Cup (RWC) 2003 held in Australia by URS Finance and Economics (2004) found that RWC2003 was estimated to have generated \$AU494 million in additional industry sales, an additional \$AU55 million in revenue to the Commonwealth Government, and more than 4000 full- and part-time jobs during 2003. The total contribution in additional Gross Domestic Product (GDP) to the Australian economy was estimated at \$AU289 million.

The economic impact study of the Sydney 2000 Olympic Games, also held in Australia, by the Centre for Regional Economic Analysis (1999) estimated that over the 12 years ending in 2005/2006, the Olympics was expected to increase New South Wales Gross State Product (GSP) by an average of almost \$AU490 million per year. The value of the impact on the Australian GDP was estimated at \$AU6.5 billion. This initial estimation was confirmed in a more recent study by Madden (2002). CGE modelling techniques were used to simulate the impact on the Australian economy in both the above-mentioned studies.

Brunet (2005) recently published a comprehensive review of the economic impact of the Barcelona Olympic Games over the period 1986-2004 and beyond. Brunet found that Barcelona's hosting of the Games was a remarkable success, and had contributed significantly to the urban regeneration and attractiveness of the city. Barcelona's use of resources and planning was exceptional and their minimising of organisational costs and careful planning with regard to the required investment and funding thereof had led to tremendous gains for the city after the event. As a result of its triumph on all levels, the Barcelona Games have become a model from a sporting, organisational, economic, social and urban planning perspective.

Kim et al. (2006) found that the impact of the 2002 FIFA World Cup on South Korea was unsatisfactory from an economic perspective. The benefits of cultural exchanges, and natural resources and cultural development were, however, found to be adequate. The lower than expected economic benefits may have been due to the fact that football has not traditionally been a major sport in Asia, but apart from these unsatisfactory gains, the 2002 FIFA World Cup was a successful event for South Koreans without any major societal and cultural problems.

Although there are many expected and perceived negative impacts from hosting a megaevent, countries and cities still compete against each other to host these events because of the expected benefits for the community and local businesses. The prospect of hosting a successful mega-event and the positive spin-offs and opportunities that this might create through international publicity and recognition (Jeong and Faulkner, 1996) often cause potential host communities to ignore any negative impacts that might occur (Kim et al, 2006).

Sports economist Holger Preuss states that every modern Olympic Games, or mega-sporting event, has had a non-sporting agenda. Preuss (2000) lists a number of objectives that these countries had in hosting events of this nature. These include:

- $\quad$ putting the country 'on the map'

- showcasing the region

- promoting the political system

- creating new trading partners 
- attracting investment

- boosting tourism

- creating jobs and business opportunities

- urban renewal, including housing and infrastructure

- building a legacy of sports infrastructure.

In another study, Ritchie and Adair (2002) emphasised the importance of legacy planning for host destinations. He stated that without careful strategic planning that keeps destination and community development in mind, it might be difficult to justify the large investments required to host the event. Comprehensive legacy planning could therefore ensure that hosting a mega-event would contribute to the development of the community, and thereby benefit residents for a long period of time.

Matheson and Baade (2004) posed the question of whether hosting mega-events is a worthwhile investment for developing nations. Building on their own previous research, they carefully weighed the arguments for and against hosting a mega-event. They found that, historically, the actual net economic impact of hosting mega-events has been very small compared to initial estimates and predictions by those promoting the events. They warned that should developing countries fail to plan adequately, hosting events of this nature could become an even worse investment for developing countries than for industrialised countries.

An economic impact assessment by Thornton (2003) of South Africa's 2010 World Cup bid and the Inspection Group Report for the 2010 FIFA World Cup (2004) highlighted some of the potential benefits to the economy, and found that the staging of the World Cup in South Africa will create significant direct and indirect economic benefits for the country's economy, with minimal tangible and intangible costs. Although the cost-benefit analysis approach used in the study is limited in its application, it remains the simplest and most easily understood method of measuring potential economic impacts. The study expected a contribution of R21 billion to the economy, and 150000 new jobs to be created. However, these findings were based on questionable income and employment multipliers, which were probably overoptimistic compared to estimates from other studies, such as Van Heerden et at. (2006).

It is clear that the outcomes from previous mega-events need to be considered in the light of South Africa's specific characteristics. Host cities face different initial conditions when first awarded mega-events. Developing countries usually require much larger capital investment in order to prepare for events of this nature. The risks and opportunity costs are therefore much more apparent (Matheson and Baade, 2004). Nonetheless, South Africa has been granted a huge opportunity and honour in being nominated as the first African nation to host the FIFA World Cup. If hosted successfully, a mega-event represents arguably the most striking manner in which a country can promote itself on the world stage. All South Africans should work together in taking full advantage of this remarkable occasion.

\section{Model and assumptions}

The model used in these simulations, UPGEM, is a 32-sector CGE model developed by the University of Pretoria and the Centre of Policy Studies. Like the majority of CGE models, UPGEM is designed for comparative-static simulations (Horridge, 2000).

A CGE model contains more variables than equations, and it is therefore necessary to choose which of the variables will be determined endogenously within the model, and which variables will be determined exogenously. The assumptions concerning the choice of endogenous and exogenous variables are known as the 'model closure' and should reflect the true economic environment in which the shocks are applied as closely as possible (De Wet, 2003).

Modifying the closure of the model allows for simulation under different assumptions, time frames, and the ability to apply different shocks to the economy. As with all economic modelling 
methodologies, it is important when interpreting the results to be aware of the assumptions and restrictions under which the model is run, and how this may influence the various outcomes. ${ }^{1}$ One should also remember that the percentage change in all exogenous variables that were not directly shocked will be zero. The numeraire in these simulations is the nominal exchange rate, phi, and is also kept exogenous.

The specific model closure used for simulating the economic impact of the 2010 FIFA World Cup is a modified version of a standard short-run closure. Given the short-run nature of the simulation, investment is therefore held constant.

The various shocks applied to the economy are grouped as follows: Scenario 1 refers to the simulation where the capital stock of the transport and construction industries are increased by $2 \%$ each and the capital stock of the communication and hotel industries by $1 \%$ each. Scenario 2 refers to the simulation where technical change in the transport industry improves productivity by $5 \%$, and in the construction and communication industries by $2 \%$ each. Scenario 3 refers to the marginal increase in tourism as a result of the tournament. This relatively small increase in tourism takes into account the crowding out effect of the tournament. Scenario 4 refers to the simulation where the demand for these capital expenditures increases during the period of the World Cup. Scenario 5 briefly analyses the impact of higher taxes as a means of financing the required expenditures ahead of the World Cup. The final scenario combines all these individual shocks to simulate the overall impact of hosting the event.

In order to correctly reflect the time period under consideration, and allow for the economic components identified above to the shocked, the following variables are held exogenous. Capital stocks, technical change, tax rates and investment are all exogenous. Employment is endogenous, and determined within the model. From a macroeconomic point of view, the impact on GDP and employment levels naturally attracts the most attention, but the results of the various shocks on an industry level are also of great value for firms and investors.

The shocks applied in the various simulations, and their respective magnitudes, were based on the general findings of the literature review in Bohlmann (2006), the proposed budget from the National Treasury Budget Review (2006) over the Medium-Term Expenditure Framework (MTEF) period, and the proposed infrastructure investment agreed to by the South African Local Organising Committee (LOC) and FIFA. The precise magnitude of event-specific capital and infrastructure expenditures remains a contentious issue nonetheless. Infrastructure specifically required for the hosting of a mega-event, such as stadiums and practice facilities, are usually easily distinguishable from other expenditures. However, there is a thin line between supporting infrastructure developments, such as transport and communication upgrades, and general infrastructure expenditure as part of, for example, the ASGISA macroeconomic framework. Although there is no doubt that these additional infrastructure developments would have occurred in time, it is assumed here that the hosting of the 2010 FIFA World Cup has shifted the majority of these expenditures sufficiently forward to be considered as supporting infrastructure for the tournament.

\section{Simulation results}

When interpreting the findings of the different shocks to the economy, it is essential to keep the type of model closure, or assumptions under which these simulations are run, in mind. Scenarios 1 to 3 measure only the impact of the benefits associated with the various shocks, and should be interpreted as such. In Scenario 4, the impact of the increased demand for the relevant goods and services is measured, and in Scenario 5, the impact of financing the associated capital expenditures on the economy is measured separately. The section concludes with a discussion on the overall impact of the 2010 FIFA World Cup on the South African economy, given the results of the individual and combined simulations.

Table 1 presents a summary of selected macroeconomic results obtained for the given shocks applied to the economy in the first three scenarios. ${ }^{2}$

In Scenario 1, we find the increase in capital stock leading to higher GDP growth and 
employment, lower prices, higher exports owing to an increase in competitiveness, and a positive impact on the balance of trade. Given the nature of the shock and model closure, these results are to be expected. Prices decrease in this scenario because of the increase in supply of capital stock. Demand is held constant in this scenario. A simple AD/AS model would clearly illustrate the decrease in prices caused by the shock, and subsequent increase in output and employment. Lower prices in the economy would improve the real exchange rate ${ }^{3}$ of the country, increasing its competitiveness in international trade and leading to a greater demand for domestic exports.

In Scenario 2, we find very similar results to that of Scenario 1 . The increase in productivity of the capital stock owing to technical progress enables output to increase relative to inputs. The net effect of this is therefore very similar to that of the first scenario. Growth in GDP and employment improves because of the relatively cheaper cost of production. Prices subsequently decrease, once again improving the real exchange rate and competitiveness of the country.

Table 1 Selected macroeconomic variables

\begin{tabular}{lccc}
\hline Macros & Scenario 1 & Scenario 2 & Scenario 3 \\
\hline$\% \Delta$ in real GDP (x0gdpexp) & 0.15 & 0.33 & 0.00 \\
$\% \Delta$ in employment (employ_iop) & 0.08 & 0.23 & 0.00 \\
$\% \Delta$ in consumer prices (p3tot) & -0.11 & -0.16 & 0.05 \\
$\% \Delta$ in price of labour (p1lab_iop) & -0.11 & -0.16 & 0.05 \\
$\% \Delta$ in total exports (x4tot) & 0.42 & 0.73 & 0.01 \\
$\% \Delta$ in competitiveness (p0realdev) & 0.16 & 0.21 & -0.06 \\
$\% \Delta$ in balance of trade (contBOT) & 0.09 & 0.14 & 0.00 \\
\hline
\end{tabular}

Scenario 3 simulates the impact of the expected increase in tourism as a result of the event. The foreign demand for domestic accommodation, transport and telecommunication services would therefore increase. Simulation results show that this would lead to higher price levels and a subsequent decrease in international competitiveness. This is caused by the increase in demand for domestic goods and services by the larger number of tourists, pushing up prices. The impact on GDP is very small, though. In Tables 2-5, the macroeconomic impacts of the various shocks are disaggregated to better understand these results.

Table 2 above shows a relatively large increase in consumption and exports in the first two scenarios. This is mostly due to the lower prices and improved competitiveness caused by the increase in supply of capital goods and related productivity, respectively. In Scenario 3, total exports increase slightly owing to the increase in foreign demand for the specified services. However, this positive impact is negated to a large extent by decreased exports from other sectors. In all three scenarios, the changes in investment and inventory levels are zero because of the nature of the short-run model closure used in these simulations. 
Table 2 Contribution to changes in GDP from the expenditure side

\begin{tabular}{lccc}
\hline contGDPexp & Scenario 1 & Scenario 2 & Scenario 3 \\
\hline Consumption & 0.05 & 0.14 & 0.001 \\
Investment (exogenous) & 0 & 0 & 0 \\
Government & 0.01 & 0.04 & 0.00 \\
Stocks (exogenous) & 0 & 0 & 0 \\
Exports & 0.10 & 0.18 & 0.003 \\
Imports* & -0.01 & -0.04 & -0.003 \\
\hline
\end{tabular}

Note: *A negative value indicates an increase in imports, from $\mathrm{Y}=\mathrm{C}+\mathrm{I}+\mathrm{G}+(\mathrm{X}-\mathrm{Z})$.

\section{Industry-level results}

In order to fully understand the magnitude and direction of change to macroeconomic variables such as GDP, employment and exports caused by the various shocks, it is essential to look at the disaggregated microeconomic or industry-specific results. The first table in this section looks at the changes in activity level of selected industries. Table 4 briefly summarises the change in basic export demand of commodities from Scenario 3.

In Table 3, the first two scenarios clearly show the increased activity in all selected industries. The increased capital stock and productivity seem to have a positive impact on most industries. Owing to the interrelatedness of most industries, this is to be expected. ${ }^{4}$ In Scenario 3, activities in the hotel accommodation, communication and transport service industries naturally increase, but show little impact on other industries. In Table 4, this result is explained more clearly. The change in basic export demands of the three shocked industries increase as expected, but the export demand for all other industries decreases by between $0.1 \%$ and $0.3 \%$.

Table 3 Percentage change in activity level of selected industries

\begin{tabular}{lccc}
\hline xltot & Scenario 1 & Scenario 2 & Scenario 3 \\
\hline Construction & 0.05 & 0.07 & 0.001 \\
Transport services & 0.88 & 2.26 & 0.13 \\
Electricity & 0.10 & 0.21 & -0.01 \\
Business activities & 0.13 & 0.28 & -0.01 \\
Food processing & 0.06 & 0.13 & -0.001 \\
Hotels & 0.84 & 0.05 & 0.09 \\
Communications & 0.64 & 1.33 & 0.03 \\
Other manufacturing & 0.09 & 0.17 & -0.03 \\
Other activities/services & 0.01 & 0.23 & -0.01 \\
\hline
\end{tabular}

Table 4 Percentage change in basic export demands of selected commodities

\begin{tabular}{lc}
\hline$x 4$ & Scenario 3 \\
\hline Transport services & 2.15 \\
Hotels & 1.24 \\
Communications & 1.44 \\
All other commodities & Decrease \\
\hline
\end{tabular}

This result is easily explained, though. Owing to the higher demand in the hotel, 
communication and transport industries, the demand curve for these services is shifted to the right, leading to higher prices and levels of output in these industries. The increase in prices for these three commodities leads to an increase in the general price level of all other commodities. As the law of demand suggests, this increase in prices would lead to a decrease in the quantity demanded for these commodities, and subsequently, lower levels of output. Furthermore, some industries would shift production to those commodities for which a higher demand exists. This would also contribute to the lower levels of output in other industries.

The Fan decomposition is most useful in determining the source of changes in activity level of industries. Tables 5 and 6 decompose the changes in output for Scenarios 1 and 2. The second column of numbers in the Fan decomposition (Local) shows us by how much we would expect local-commodity output to change, if output of the local commodity increased in line with the change in domestic demand for commodity regardless of source, i.e., domestic or imported. The third column (Domestic) can be interpreted as the amount by which local-commodity output changes because of a relative price change favouring import replacement. The fourth column (Export) shows the contribution to the change in the output of the local commodity, brought about by the changes in exports. The last column (Total) is the sum of the values in Columns 2 to 4 , and should correspond to the values in Table $3 .^{5}$ The decomposition of Fan therefore aims to show the relative magnitude of these three contributions to output change (Horridge, 2000). The results found are in line with expectations, given the lower price levels generated in the first two scenarios and the structure of the economy.

Table 5 Fan decomposition of selected industries in Scenario 1

\begin{tabular}{lcccc}
\hline Fandecomp & Local & Domestic & Export & Total \\
\hline Construction & 0.02 & 0.01 & 0.002 & 0.03 \\
Transport services & 0.36 & 0.07 & 0.46 & 0.89 \\
Electricity & 0.11 & 0.00 & -0.01 & 0.10 \\
Business activities & 0.12 & 0.01 & 0.01 & 0.14 \\
Food processing & 0.05 & -0.01 & 0.02 & 0.06 \\
Hotels & 0.18 & 0.07 & 0.54 & 0.79 \\
Communications & 0.44 & 0.05 & 0.15 & 0.64 \\
Other manufacturing & 0.02 & -0.01 & 0.08 & 0.09 \\
Other activities/services & 0.08 & 0.001 & 0.01 & 0.09 \\
\hline
\end{tabular}


Table 6 Fan decomposition of selected industries in Scenario 2

\begin{tabular}{lcccc}
\hline Fandecomp & Local & Domestic & Export & Total \\
\hline Construction & 0.04 & 0.01 & 0.003 & 0.05 \\
Transport services & 0.91 & 0.18 & 1.17 & 2.26 \\
Electricity & 0.24 & 0.00 & -0.02 & 0.22 \\
Business activities & 0.27 & 0.003 & 0.007 & 0.28 \\
Food processing & 0.13 & -0.01 & 0.02 & 0.14 \\
Hotels & 0.16 & -0.02 & -0.07 & 0.07 \\
Communications & 0.94 & 0.09 & 0.29 & 1.32 \\
Other manufacturing & 0.06 & -0.01 & 0.11 & 0.16 \\
Other activities/services & 0.18 & 0.001 & 0.01 & 0.19 \\
\hline
\end{tabular}

Table 7 shows the changes in employment by industry in the first two scenarios. The increase in capital stock and productivity of capital decreases the demand for labour in the construction and transport industries. This is due to the fact that capital is now cheaper and more readily available. The use of labour is therefore replaced with the use of capital. The communication industry still shows a marginal increase in employment owing to the smaller change in capital stock and productivity. The effect of the increase in overall demand, and partly labour, is therefore stronger than the relatively cheaper capital reducing the demand for labour. For all other sectors, employment increases in line with the increase in total output shown in Table 3 previously.

Table 7 Percentage change in employment by industry (employ_op)

\begin{tabular}{lcc}
\hline employ_op & Scenario 1 & Scenario 2 \\
\hline Construction & -1.13 & -1.12 \\
Transport services & -0.25 & -0.70 \\
Electricity & 0.28 & 0.60 \\
Business activities & 0.18 & 0.38 \\
Food processing & 0.14 & 0.29 \\
Hotels & 0.40 & 0.20 \\
Communications & 0.24 & 0.55 \\
Other manufacturing & 0.19 & 0.34 \\
Other activities/services & 0.02 & 0.28 \\
\hline
\end{tabular}

In the third scenario, simulating the impact of increased tourism inflow, employment results are also very much in line with the results from changes in total output. Employments in the hotel, transport and communications industry increase. Employments in all but two of the remaining industries decline, however. Nonetheless, the net effect in total employment, as shown in Table 1 , is still a marginal increase. As discussed earlier, the nature of these shocks are very specific, and the results are a disaggregation of all the events that would occur during the 2010 FIFA World Cup period. Thus far, only the increased capital stock, productivity gains, and tourist demand for certain goods and services have been simulated. In the following scenario, we simulate the increased local demand for these capital goods during the event period.

The stadiums and supporting infrastructure built for the World Cup will naturally be in great demand during this time. Scenario 4 separates this impact and analyses the results. Table 8 summarises the most important macroeconomic results. 
Table 8 Selected macroeconomic variables

\begin{tabular}{lc}
\hline Macros & Scenario 4 \\
\hline$\% \Delta$ in real GDP (x0gdpexp) & 0.61 \\
$\% \Delta$ in employment (employ_iop) & 1.11 \\
$\% \Delta$ in consumer prices (p3tot) & 1.43 \\
$\% \Delta$ in price of labour (p1lab_iop) & 1.43 \\
$\% \Delta$ in total exports (x4tot) & -3.03 \\
\hline
\end{tabular}

It is clearly evident that the increased demand for these capital goods and services during the event would shift the demand curve to the right, increasing general price, output and employment levels. Higher prices would, of course, decrease the country's international competitiveness, leading to lower exports. At an industry level, the outputs of the goods and services in higher demand naturally increase the most, with related industries also showing marginal increases in output growth.

One of the major concerns any host country of a mega-event such as the FIFA World Cup has is how to finance these event-specific capital expenditures, and what the opportunity cost of this is to the economy. Moreover, finding the most efficient manner of financing these expenditures is of great importance. It is unlikely given the macroeconomic environment in South Africa that tax rates would be increased. The possibility of a cut in tax rates would, however, be greatly diminished. Alternatively, should South Africa not have hosted the World Cup, many government expenditures, including the R8 billion specifically earmarked for World Cup stadia development, would not have occurred. From a psychological perspective, it is argued that agents react differently to, for example, having to pay $1 \%$ more taxes as opposed to not receiving a $1 \%$ tax cut (Kahneman, 2003). However, for simplicity, it is assumed here that the impacts of these two alternative scenarios are the same. In Scenario 5, general sales tax by government is increased by $0.5 \%$ to simulate the impact of financing the capital expenditures. The results show a relatively large negative impact on most macroeconomic variables, with both GDP and employment declining. On an industry level, all sectors are adversely affected because of lower overall demand.

\section{Overall impact}

Thus far, we have shown separately the impact of each shock to the economy as a result of hosting the 2010 FIFA World Cup. When running these different scenarios simultaneously, the model shows the overall impact of the event on the economy. Table 9 briefly summarises the most important macroeconomic results.

Table $9 \quad$ Selected macroeconomic variables

\begin{tabular}{lcc}
\hline Macros & Overall (low tax) & Overall (high tax) \\
\hline$\% \Delta$ in real GDP (x0gdpexp) & 0.69 & 0.08 \\
$\% \Delta$ in employment (employ_iop) & 0.72 & -0.35 \\
$\% \Delta$ in consumer prices (p3tot) & 1.21 & 1.24 \\
\hline
\end{tabular}

It should be remembered that the time period under consideration is relatively short. Many of the associated benefits of hosting a mega-event, such as increased FDI, are therefore not included. The impact of financing by the government also plays a significant role. In the high- 
tax scenario in Table 9, it is assumed that the majority of the expenditure would be financed through higher taxes. Under this scenario, there is a negligible increase in GDP, with lower overall employment and high price levels. In this case, the economic costs of the event therefore seems to outweigh the economic benefits. However, should taxes only be increased by $0.5 \%$, under the assumption that future investment, GDP growth and taxes generated would finance the remaining amount, both GDP and employment would then show a positive result in the short term, with prices still increasing. On an industry level, the construction, transport, communications, and hotel industries remain the biggest winners in both scenarios.

In reality, there remains a great deal of uncertainty regarding the overall impact of hosting the World Cup on the economy. From a purely economic perspective, it is hard to imagine that there would be any significant impact on GDP in the short term. Similarly, employment might increase in the short term as a result of construction activities, but remain unchanged in the longer term as demand for labour decreases again. However, if the World Cup is a considerable success, and leads to large sums of foreign investment and increased domestic activity, both GDP and employment could potentially increase even further in the long term.

Many intangible factors were also not explicitly considered. The organising of the World Cup would place immense strain on the capacity of local and provincial governments. Other negative aspects associated with mega-events, such as increased traffic congestion and petty crime, were also not taken into account. Perhaps the most important intangible factor associated with the hosting of a mega-event is the pride or happiness factor. Hosting a successful mega-event and increasing the profile of the country, undoubtedly increases the pride residents have towards their country. The long-term impact of a happier population could be significant, and could be an interesting topic for future research.

\section{Conclusion}

Sports have transcended their position as merely a form of leisure or entertainment, to one of the biggest industries in the world today. Since the introduction of live television broadcasts, these events have dramatically risen in popularity. Subsequently, the money and prestige involved in these sporting events have also increased.

The hosting of mega-events has become more fiercely contested than ever, with the prospect of a large economic windfall luring potential host cities to the bidding process. However, this study emphasises the fact that without proper planning and correct investment decisions, megaevents could indeed become a fiscal nightmare for their hosts. Cities have become increasingly aware of the immense cost associated with hosting modern events, and are placing a lot more emphasis on legacy planning.

The focus of this study is on South Africa's hosting of the 2010 FIFA World Cup. A number of considerations are highlighted in order for South Africa to derive the maximum benefit from hosting the event. A CGE model of the South African economy is used to predict the economic impact of hosting the event on the local economy. Overall, the real economic impact was found to be negligible given the relatively short time period under consideration. Various industries, such as construction, transport and accommodation, would naturally benefit during this period. It is plausible that many of the macroeconomic benefits associated with hosting the event would only be fully realised in the longer term.

It is important as hosts of the 2010 FIFA World Cup to maximise this opportunity. Events of this nature can be viewed as a massive marketing campaign for the country. A lot of money has to be spent to create a successful advert initially, but the longer-term gains will more often than not outweigh the costs. However, hosting a successful World Cup does not necessarily imply hosting the most expensive World Cup with regard to stadiums and supporting infrastructure. Giving the event a distinctly African flavour, without too many extravagant bells and whistles attached, could prove to be just as effective. The focus should rather be on investing heavily in 
supporting infrastructure, such as transport and communication services, than excessive stadiums with a low net worth after the event. That said, given the possibility of future megaevents, stadiums should be upgraded and carefully maintained on a regular basis. The prospect of building one major iconic stadium could also be considered. As always, the sustainability of these investments is critical to its success. Given our status as a developing nation, the opportunity costs of such large and visible expenditures are much more apparent, and therefore politically sensitive.

Legacy planning has become the buzz word in hosting a mega-event. South Africa has been given a huge opportunity to showcase itself. Some might argue that it is an opportunity that comes at too great a cost. However, given proper long-term planning and vision, FIFA 2010 could turn out to be the most profitable investment in this country's history.

\section{References}

Bohlmann, H.R. (2006) 'Predicting the economic impact of the 2010 FIFA World Cup on South Africa', Department of Economics Working Paper Series 2006-11, University of Pretoria, www.up.ac.za/up/web/en/academic/economics/index.html.

Brunet, F. (2005) 'The economic impact of the Barcelona Olympic Games, 1986-2004', www.olympicstudies.uab.es.

Centre for Regional Economic Analysis (1999) 'Economic impact study of the Sydney 2000 Olympic Games', Report received via e-mail from J.R. Madden.

De Wet, T.J. (2003) "The effect of a tax on coal in South Africa: a CGE analysis', PhD thesis, University of Pretoria, http://upetd.up.ac.za/upetd.htm.

Horridge, M. (2000) 'ORANI-G: a generic single-country computable general equilibrium model', CoPS Working Paper OP-93, Centre of Policy Studies, Monash University.

Jeong, G. and Faulkner, B. (1996) 'Resident perceptions of mega-event impacts: The Taejon International Exposition Case', Festival Management and Event Tourism, Vol. 4, pp.3-14.

Kahneman, D. (2003) 'A psychological perspective on economies', The American Economic Review, Vol. 93, No. 2, pp. 162-168.

Kim, H.J., Gursoy, D. and Lee, S. (2006) 'The impact of the 2002 World Cup on South Korea: comparisons of pre- and post-games', Journal of Tourism Management, Vol. 27, No. 1, pp.86-96.

Madden, J.R. (2002) 'The economic consequences of the Sydney Olympics: the CREA/Arthur Andersen study', Current Issues in Tourism, Vol. 5, No. 1, pp.7-20.

Matheson, V.A. and Baade, R.A. (2004) 'Mega-sporting events in developing nations', Working Paper 0404, College of the Holy Cross, Department of Economics.

National Treasury Budget Review (2006) www.treasury.gov.za.

Preuss, H. (2000) Economics of the Olympic Games - Hosting the Games 1972-2000, Walla Walla Press in conjunction with the Centre for Olympic Studies.

Ritchie, B. and Adair, D. (2002) 'The growing recognition of sport tourism', Current Issues in Tourism, Vol. 5, No. 1, pp. 1-6.

Thornton, G. (2003) SA 2010 Soccer World Cup Bid Executive Summary, www.polity.org.za.

URS Finance and Economics (2004) 'Economic impact of the Rugby World Cup 2003 on the Australian economy - post analysis', www.ausport.gov.au.

Van Heerden, J.H., Gerlagh, J., Blignaut, J., Horridge, M., Hess, S., Mabugu, R. and Mabugu, M. (2006) 'Searching for triple dividends in South Africa: fighting $\mathrm{CO}_{2}$ pollution and poverty while promoting growth', Energy Journal, Vol. 27, No. 2, pp.113-142.

\section{Bibliography}

Beis, D.A., Loucopoulos, P. and Zografos, K.G. (2006) 'PLATO helps Athens win gold: Olympic Games knowledge modelling for organizational change and resource management', Informs, Vol. 36, No. 1, pp.26-42.

Canadian Sports Tourism Alliance (2003) 'Canada Winter Games 2003 economic impact assessment', www.canadiansporttourism.com.

Deccio, C. and Baloglu, S. (2002) 'Nonhost community resident reactions to the 2002 Winter Olympics: the spillover impacts', Journal of Travel Research, Vol. 41, August, pp.46-56.

Du Toit, C.B., Van Eyden, R. and Ground, M. (2005) 'Does South Africa have the potential and capacity to 
grow at 7 percent? A labour market perspective', Paper Presented at the Tenth Annual Econometric Conference for Africa: AERC, Nairobi, Kenya, 6-8 July.

FIFA (2006) Various Articles and Reports from the Official Website of FIFA, www.fifa.com.

Fredline, E. and Faulkner, B. (2002) 'Variations in residents' reactions to major motorsport events', Event Management, Vol. 7, pp. 115-125.

Frost, M. (2003) 'The greatest game ever played', Time Warner Paperbacks, Great Britain.

Hone, P. (2005) 'Assessing the contribution of sport to the economy', School Working Paper 2005/11, School of Accounting, Economics and Finance, Deakin University.

International Monetary Fund (2005a) 'Post apartheid South Africa: the first ten years', in M. Nowak and L.A. Ricci (Eds.) International Monetary Fund, Washington, DC.

International Monetary Fund (2005b) 'South Africa: selected issues', IMF Country Report No. 05/345, International Monetary Fund, Washington, DC.

Jordaan, J.C. (2004) 'Foreign direct investment and neighbouring influences', PhD thesis, University of Pretoria, http://upetd.up.ac.za/upetd.htm.

LA Sports and Entertainment Commission (n.d.) Economic Impact of Major Sporting and Entertainment Events, www.lasec.net.

Lee, C. and Taylor, T. (2003) 'Critical reflections on the economic impact assessment of a mega-event: the case of 2002 FIFA World Cup', Journal of Tourism Management, Vol. 26, No. 4, pp.595-603.

Madden, J.R., Preuss, H. and Szymanski, S. (2005) 'Enhancing the modelling and analysis of impacts and risks of the 2010 FIFA World Cup', Presentation at the National Treasury Modelling Workshop, Kievitskroon, Pretoria, 28-30 November.

Mlambo-Ngcuka, P. (2006) 'Background document: a catalyst for accelerated and shared growth - South Africa (ASGISA)', Media briefing on 6 February 2006, www.info.gov.za.

PriceWaterhouseCoopers (2002) 'Business and economic benefits of the Sydney 2000 Olympic Games - a collation of evidence', www.gamesinfo.com.au.

Sheard, R. (2001) Olympic Stadia and the Future, Published in the Documents of the Museum Collection, International Olympic Committee.

Simpson, M. (2006) 'The 2010 FIFA World Cup: planning challenges and approaches', Presentation at the ERSA Infrastructure and Growth Workshop, Twelve Apostles Hotel, Cape Town, 29-31 May.

South African Reserve Bank (2005) Quarterly Bulletin - June 2005, No. 236, Pretoria, South African Reserve Bank.

Statistics South Africa (2002) Final Social Accounting Matrix 1998, No. 04-03-02 (1998), Pretoria, Statistics South Africa.

Statistics South Africa (2004) Overview of the 1998 Social Accounting Matrix, Pretoria, Statistics South Africa.

Statistics South Africa (2006) Labour Force Survey - September 2005, P0210, Pretoria, Statistics South Africa.

Szymanksi, S. (2003) 'The assessment: the economics of sport', Oxford Review of Economic Policy, Vol. 19 , No. 4, pp.467-477.

Tibbott, R. (2001) 'Olympic economies', Locum Destination Review, Vol. 3.

United Nations (2005) The Millennium Development Goals Report 2005, New York, United Nations.

United Nations Conference on Trade and Development (2005) Economic Development in Africa: Rethinking the Role of Foreign Direct Investment, Geneva, United Nations.

United Nations Development Programme (2005) Human Development Report 2005: International Cooperation at a Crossroads, New York, United Nations.

Watts, J. (2002) 'Japanese stadiums turn into white elephants', The Guardian, 2 July.

World Travel and Tourism Council (2002) South Africa: The Impact of Travel \& Tourism on Jobs and the Economy, United Kingdom.

\section{Notes}

1 See Horridge (2000) and De Wet (2003) for a full discussion on model closures and how the CGE model is solved within GEMPACK.

2 Scenarios 1, 2 and 3 refer to the increase in capital stock, productivity and tourism, respectively, as a result of hosting the 2010 HFA World Cup.

3 The real exchange rate of a country is the ratio of foreign prices to domestic prices measured in the same currency, and is defined by the equation $R=e P_{f} / P$. 
4 The sales matrix from the database file in the model clearly depicts the relationship between the various sectors and the destination of their sales.

5 Minor discrepancies may occur due to rounding. 